\title{
ОСОБЕННОСТИ ПРИМЕНЕНИЯ ЗАКОНОДАТЕЛЬСТВА ОБ АНТИКОРРУПЦИОННОЙ ЭКСПЕРТИЗЕ
}

\begin{abstract}
Аннотация: Действующее российское законодательства предусматривает в качестве одного из направлений противодействия коррупции осуществление антикоррупционной экспертизы нормативно-правовых актов и проектов нормативно-правовых актов органов государственной власти и органов местного самоуправления (Федеральный закон от 25 декабря 2008 года № 273-Ф3 «О противодействии коррупции»; Федеральный закон от 17 июля 2009 года № 172-Ф3 «Об антикоррупционной экспертизе нормативно-правовых актов и проектов нормативно-правовых актов»). Настоящая статья посвящена исследованию вопросов проведения независимой антикоррупционной экспертизы, особенностей и рекомендаций по применению на практике нормативно-правовых актов, регламентирующих процесс осуществления данной экспертизы. Методологической основой исследования явилась совокупность общенаучных и специальных методов постижения объективной социально-правовой действительности в исследуемой области: методы анализа, синтеза, систематизации и обобщения, формально-логический, статистический и социологический методы. В статье исследуются и анализируются важнейшие принципы и аспекты применения норм российского законодательства о проведении независимой антикоррупционной экспертизы. В процессе исследования, исходя из анализа правоприменительной практики были выявлены существующие проблемы в рассматриваемой срере и предложены возможные способы их устранения. Выводы статьи могут быть полезны органам государственной власти и органам местного самоуправления, правоприменительным органам, а также гражданам и юридическим лицам, аккредитованным Министерством юстиции Российской Федерации в качестве независимых экспертов.

Ключевые слова: органы государственной власти, органы местного самоуправления, нормативно-правовые акты, проекты нормативно-правовых актов, эффективность, независимый эксперт, принципы, субъекты антикоррупционной экспертизы, борьба с коррупцией, антикоррупционная экспертиза.
\end{abstract}

A нтикоррупционной экспертизой признаётся деятельность федеральных органов государственной власти, органов государственной власти субъектов Российской Федерации, органов местного самоуправления, институтов гражданского общества, организаций и физических лиц в пределах их полномочий, имеющая целью предупреждение коррупции, в том числе выявление и последующее устранение причин коррупции (профилактика коррупции); выявление, предупреждение, пресечение, раскрытие и расследование коррупционных правонарушений (борьба с коррупцией); минимизацию и (или) ликвидацию последствий коррупционных правонарушений.

Предполагается, что эффективная антикоррупционная экспертиза может возыметь превентивное значение при пресечении коррупционных преступлений посредством выявления коррупционных и коррупциогенных составляющих того или иного акта или проекта.

Коррупциогенными факторами являются положения нормативных правовых актов (проектов нормативных правовых актов), устанавливающие для правоприменителя необоснованно широкие пределы усмотрения или возможность необоснованного применения исключений из общих правил, а также положения, содержащие неопределенные, трудновыполнимые и (или) обременительные требования к гражданам и организациям и тем самым создающие условия для проявления коррупции.

Основными принципами организации антикоррупционной экспертизы нормативных правовых актов (проектов нормативных правовых актов) являются:

1) обязательность проведения антикоррупционной экспертизы проектов нормативных правовых актов;

2) оценка нормативного правового акта во взаимосвязи с другими нормативными правовыми актами;

3) обоснованность, объективность и проверяемость результатов антикоррупционной экспертизы нормативных правовых актов (проектов нормативных правовых актов); 
4) компетентность лиц, проводящих антикоррупционную экспертизу нормативных правовых актов (проектов нормативных правовых актов);

5) сотрудничество федеральных органов исполнительной власти, иных государственных органов и организаций, органов государственной власти субъектов Российской Федерации, органов местного самоуправления, а также их должностных лиц с институтами гражданского общества при проведении антикоррупционной экспертизы нормативных правовых актов (проектов нормативных правовых актов).

Антикоррупционная экспертиза нормативных правовых актов (проектов нормативных правовых актов) проводится:

1) прокуратурой Российской Федерации;

2) федеральным органом исполнительной власти в области юстиции;

3) органами, организациями, их должностными лицами;

4) институтами гражданского общества и гражданами.

При этом указанные органы и лица, исходя из смысла законодательства о противодействии коррупции, при осуществлении антикоррупционной экспертизы должны взаимодействовать, в противном случае данная деятельность не будет носить комплексный характер.

Данная позиция нашла также отражение и в Приказе Генерального прокурора Российской Федерации от 28 декабря 2009 года № 400 «Об организации проведения антикоррупционной экспертизы нормативных правовых актов», согласно которому при реализации соответствующих полномочий прокуроры должны наладить взаимодействие с иными субъектами антикоррупционной экспертизы, в частности, проводящими независимую экспертизу на коррупциогенность.

На страницах юридической печати обоснованно отмечается, что органичное и взаимодополняюеее сочетание институтов публичной власти и гражданского общества способно конструктивно взаимодействовать и олицетворяет собой механизм обеспечения законности ${ }^{1}$. Участие институтов гражданского общества и граждан в независимой антикоррупционной экспертизе является реальным механизмом противодействия коррупции. 1 См.: Винокуров А.Ю. Законность в Российской Федера-
ции. М.: Контракт, 2008. С. 114.
Постановлением Правительства Российской Федерации от 26 февраля 2010 года № 96 утверждены Правила проведения антикоррупционной экспертизы нормативных правовых актов и проектов нормативных правовых актов в целях выявления в них положений, способствующих созданию условий для проявления коррупции. Данные Правила должны подлежать строгому соблюдению всеми аккредитованными независимыми экспертами, осуществляющими антикоррупционную экспертизу.

В 2010-2013 гг. Департаментом конституционного законодательства Минюста России рассмотрено свыше 393 заявления об аккредитации в качестве независимых экспертов, из них 828 от физических лиц, 164 - от юридических, 28 из них - региональными отделениями Общероссийской общественной организации «Ассоциация юристов России».

В целях обеспечения возможности проведения независимой антикоррупционной экспертизы государственные органы и органы местного самоуправления размещают проекты нормативных правовых актов в сети Интернет. В большинстве ведомств такой порядок закреплен внутренними приказами ${ }^{2}$.

Аккредитованные Минюстом России эксперты при выявлении в нормативных правовых актах (проектах нормативных правовых актов) коррупциогенных факторов должны составить заключение. Особое внимание при этом должно уделяться взаимодействию независимых экспертов с органами прокуратуры Российской Федерации, обладающими необходимым потенциалом для реализации полномочий по противодействию коррупции в соответствии с Федеральным законом от 17 января 1992 года № 2202-1 «0 прокуратуре Российской Федерации». Подобное взаимодействие обусловлено, главным образом, заинтересованностью органов прокуратуры в информационном обеспечении. В тех случаях, когда органами и должностными лицами, принявшими оспариваемым нормативно-правовой акт, заключению независимого эксперта не было придано должного значения, органы прокуратуры могут внести требование об изменении нормативного правового акта, при этом такое требование подлежит обязательному рассмотрению.

\footnotetext{
2 См.: Корякин В.М. Организация антикоррупционной экспертизы правовых актов в Минобороны России и других органах государственной власти: сравнительно-правовой анализ // Военное право. 2010. № 2.
} 
В то же время, как показывает анализ правоприменительной практики, в настоящий момент взаимодействие институтов гражданского общества с органами прокуратуры по вопросам проведения антикоррупционной экспертизы не всегда отличается должной активностью. Более $70 \%$ опрошенных отрицательно ответили на вопрос о наличии случаев обращения в органы прокуратуры с просьбой проверить нормативные правовые акты на коррупциогенность. Положительных ответов оказалось менее $10 \%$. Как правило, в органы прокуратуры обращались общественные организации, представители субъектов малого и среднего предпринимательства ${ }^{3}$.

Вместе с тем активная позиция гражданского общества могла бы во многом повысить эффективность противодействия коррупционным преступлениям.

Федеральный закон «Об антикоррупционной экспертизе нормативных правовых актов и проектов нормативных правовых актов» (ст. 5) обязывает орган, организацию или должностное лицо, которым адресована независимая антикоррупционная экспертиза, направлять мотивированный ответ независимому эксперту, за исключением случаев, когда в заключении отсутствует предложение о способе устранения выявленных коррупциогенных факторов.

Данное положение Закона было воспринято также рядом ведомственных актов. В частности, п. 6 Порядка проведения антикоррупционной экспертизы нормативных правовых актов (проек- тов нормативных правовых актов) Федеральной службы по финансовым рынкам устанавливает, что по результатам рассмотрения заключения независимого эксперта профильным управлением гражданину или организации, проводившим независимую антикоррупционную экспертизу, направляется мотивированный ответ, за исключением случаев, когда в заключении отсутствует предложение о способе устранения выявленных коррупциогенных факторов.

Как представляется, закрепление данного положения в Законе «Об антикоррупционной экспертизе нормативных правовых актов и проектов нормативных правовых актов» имело целью конкретизацию, обеспечение принципа определённости независимой экспертизы, исключение необоснованной критики и необъективности.

При этом исходя из смысла законодательства Российской Федерации, в случае отсутствия в заключении независимого эксперта предложения о способе устранения выявленных коррупциогенных факторов мотивированный ответ гражданином или юридическим лицом может быть получен в соответствии с Федеральным законом «Об обеспечении доступа к информации о деятельности государственных органов и органов местного самоуправления», устанавливающему обязанность государственных органов и органов местного самоуправления размещать на сайте обобщенную информацию о результатах рассмотрения обращений и принятых мерах.

\section{Библиография:}

1. Винокуров А.Ю. Законность в Российской Федерации. М.: Контракт, 2008.

2. Какителашвили М.М., Непомнящий В.А. Взаимодействие органов прокуратуры с институтами гражданского общества при проведении антикоррупционной экспертизы // Вестник Академии Генеральной прокуратуры. - 2011. - № 1.

3. Корякин В.М. Организация антикоррупционной экспертизы правовых актов в Минобороны России и других органах государственной власти: сравнительно-правовой анализ // Военное право. 2010. № 2.

4. Кудашкин А.В., Дмитриев Д.А. К вопросу о необходимости совершенствования правового регулирования проведения органами прокуратуры антикоррупционной экспертизы в целях повышения ее эффективности // Административное и муниципальное право. - 2011. - 4. - С. 87-91.

5. Кудашкин А.В. К вопросу о предмете и объекте антикоррупционной экспертизы // Административное и муниципальное право. - 2010. - 8. - С. 26-30.

6. О. В. Калтыга Проблемы антикоррупционной экспертизы нормативно-правовых актов и их проектов на современном этапе развития Российского государства // Политика и общество. - 2012. - 7. - С. 32-38.

3 См.: Какителашвили М.М., Непомнящий В.А. Взаимодействие органов прокуратуры с институтами гражданского общества при проведении антикоррупционной экспертизы // Вестник Академии Генеральной прокуратуры. - 2011. № $1 .-$ C. 15-19. 
Административное и муниципальное право 8 (80) 2014

7. Куракин А.В., Юлегина Е.И. Административные регламенты исполнения государственных функций и оказания государственных услуг в области осуществления антикоррупционной экспертизы нормативных правовых актов и их проектов // NB: Административное право и практика администрирования. - 2013. - 6. - С. 54-82. URL: http://www.e-notabene.ru/al/article_9040.html

8. Астанин В.В. Методологические основы мониторинга правоприменения в контексте научной доктрины и требований законодательства // Административное и муниципальное право. - 2012. 4. - С. 5-13.

9. Астанин В.В. Проблемы мониторинга правоприменения в целях реализации антикоррупционной политики // Административное и муниципальное право. - 2012. - 6. - С. 5-11.

10. Антошина Н.М. О мониторинге применения законодательства Российской Федерации о государственной гражданской службе // Административное и муниципальное право. - 2011. - 4. - С. 43-48.

11. Лафитский В.И. Обзор работы 15-й Международной антикоррупционной конференции // Журнал зарубежного законодательства и сравнительного правоведения. - 2012. - 5. - С. 129-135.

\section{References:}

1. Vinokurov A.Yu. Zakonnost' v Rossiiskoi Federatsii. M.: Kontrakt, 2008.

2. Kakitelashvili M.M., Nepomnyashchii V.A. Vzaimodeistvie organov prokuratury s institutami grazhdanskogo obshchestva pri provedenii antikorruptsionnoi ekspertizy // Vestnik Akademii General'noi prokuratury. 2011. - № 1 .

3. Koryakin V.M. Organizatsiya antikorruptsionnoi ekspertizy pravovykh aktov v Minoborony Rossii i drugikh organakh gosudarstvennoi vlasti: sravnitel'no-pravovoi analiz // Voennoe pravo. 2010. № 2.

4. Kudashkin A.V., Dmitriev D.A. K voprosu o neobkhodimosti sovershenstvovaniya pravovogo regulirovaniya provedeniya organami prokuratury antikorruptsionnoi ekspertizy v tselyakh povysheniya ee effektivnosti // Administrativnoe i munitsipal'noe pravo. - 2011. - 4. - C. 87-91.

5. Kudashkin A.V. K voprosu o predmete i ob"ekte antikorruptsionnoi ekspertizy // Administrativnoe i munitsipal'noe pravo. - 2010. - 8. - C. 26-30.

6. 0. V. Kaltyga Problemy antikorruptsionnoi ekspertizy normativno-pravovykh aktov i ikh proektov na sovremennom etape razvitiya Rossiiskogo gosudarstva // Politika i obshchestvo. - 2012. - 7. - C. 32-38.

7. Kurakin A.V., Yulegina E.I. Administrativnye reglamenty ispolneniya gosudarstvennykh funktsii i okazaniya gosudarstvennykh uslug v oblasti osushchestvleniya antikorruptsionnoi ekspertizy normativnykh pravovykh aktov i ikh proektov // NB: Administrativnoe pravo i praktika administrirovaniya. — 2013. - 6. - C. 54-82. URL: http://www.e-notabene.ru/al/article_9040.html

8. Astanin V.V. Metodologicheskie osnovy monitoringa pravoprimeneniya v kontekste nauchnoi doktriny i trebovanii zakonodatel'stva // Administrativnoe i munitsipal'noe pravo. - 2012. - 4. - C. 5-13.

9. Astanin V.V. Problemy monitoringa pravoprimeneniya v tselyakh realizatsii antikorruptsionnoi politiki // Administrativnoe i munitsipal'noe pravo. - 2012. - 6. - C. 5-11.

10. Antoshina N.M. O monitoringe primeneniya zakonodatel'stva Rossiiskoi Federatsii o gosudarstvennoi grazhdanskoi sluzhbe // Administrativnoe i munitsipal'noe pravo. - 2011. - 4. - C. 43-48.

11. Lafitskii V.I. Obzor raboty 15-i Mezhdunarodnoi antikorruptsionnoi konferentsii // Zhurnal zarubezhnogo zakonodatel'stva i sravnitel'nogo pravovedeniya. - 2012. - 5. - C. 129-135. 